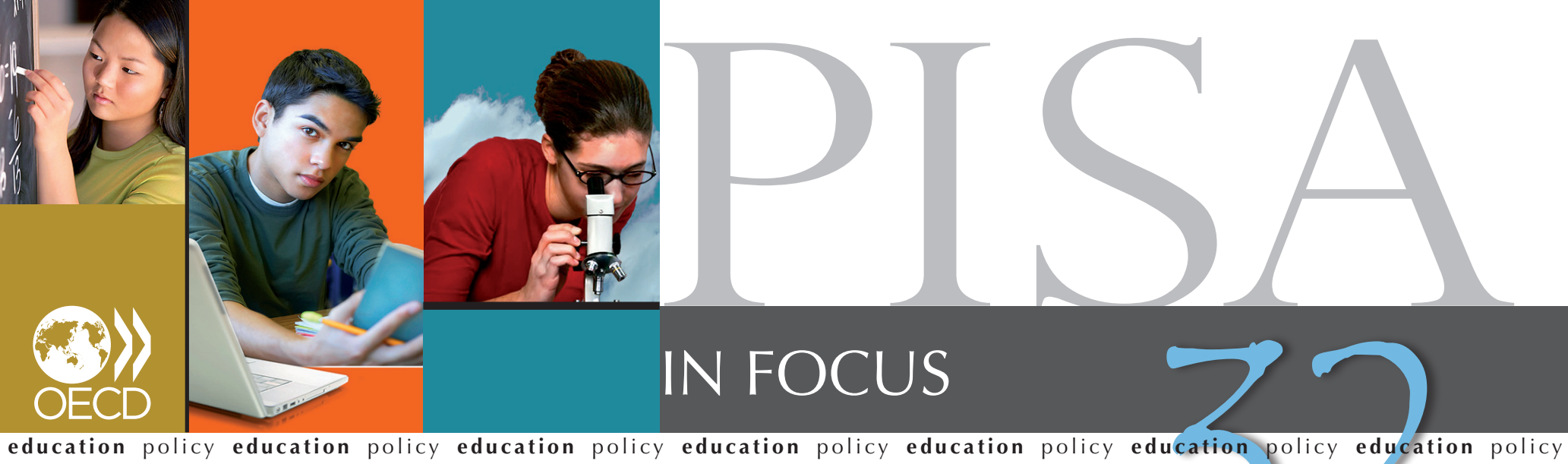

\title{
Do students perform better in schools with orderly classrooms?
}

- Most students enjoy orderly classrooms for their language-of-instruction lessons.

- Socio-economically disadvantaged students are less likely to enjoy orderly classrooms than advantaged students.

- Orderly classrooms - regardless of the school's overall socio-economic profile are related to better performance.

A good climate for learning almost everywhere.
Imagine a class of 15-year-olds. What image springs to mind? Neat rows of desks at which students silently sit, passively absorbing their teacher's every

word? Or semi-controlled chaos, where students talk - or shout - to each other across the classroom while the teacher tries desperately to attract their attention? Fortunately, the reality lies somewhere between these two extremes. According to the reports of students who participated in PISA 2009, most students in most of the PISA-participating countries and economies enjoy orderly classrooms. On average across OECD countries, for example, four out of five students reported that only occasionally do students not work well in class because of distractions from other students. Around three out of four students also reported that only occasionally do their teachers have to wait a long time for students to quiet down; and more than two out of three students reported that never or hardly ever is there noise and disorder in their classrooms.

There are some countries and economies where the disciplinary climate is even more conducive to learning. For example, fewer than one in ten students in Korea and Thailand reported that they cannot work well in class because of disruptions; fewer than one in ten students in Japan, Kazakhstan and Thailand reported that they have to wait a long time after class begins to start working; and fewer than one in ten students in Japan, Kazakhstan and Shanghai-China reported that their teacher has to wait a long time for students to quiet down before they can begin class. 
Percentage of students who reported that the following never or hardly ever happens, or happens only in some of their language-of-instruction lessons:

Students cannot work well.

- The teacher has to wait a long time for students to quiet down.

There is noise and disorder.

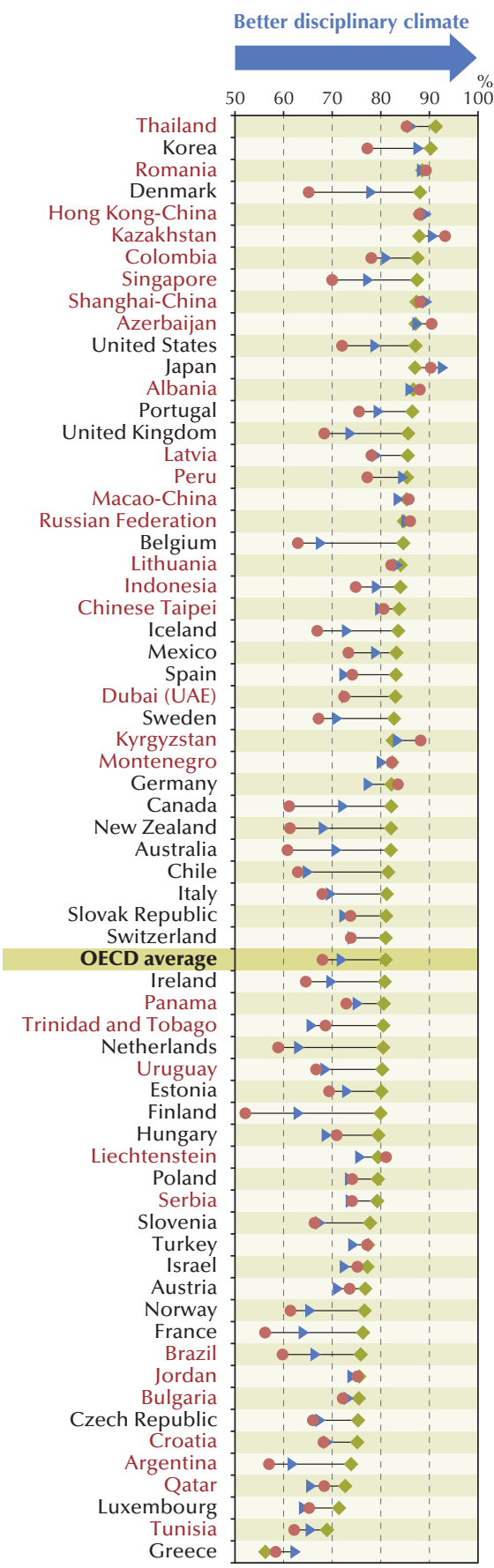

Note: OECD countries are shown in black.

Source: PISA 2009 Results: What Makes a School Successful? Resources, Policies and Practices, Figure IV.4.2.

StatLink 完15 $\mathrm{http}: / / \mathrm{dx}$.doi.org/10.1787/888932343418
By contrast, nearly one in two students in Greece reported that they can't work well in most or all lessons; nearly one in two in Croatia, Greece and Slovenia reported that students don't listen to what the teacher says; and nearly one in two students in Argentina, Finland, France, Greece and the Netherlands reported that there is noise and disorder in their classrooms.
In PISA 2009, students were asked to respond to the following questions:

\section{How often do these things happen in your language \\ of instruction lessons?}

(Please tick only one box in each row)

$$
\begin{gathered}
\text { Never or In some In most In all } \\
\text { hardly }
\end{gathered}
$$

a) Students don't listen to what the teacher says

b) There is noise and disorder

c) The teacher has to wait a long time for the students to quieten down

d) Students cannot work well

e) Students don't start working for a long time after the lesson begins

Students' views on how conducive classrooms are to learning were combined to develop a composite index to measure the disciplinary climate in their schools. 


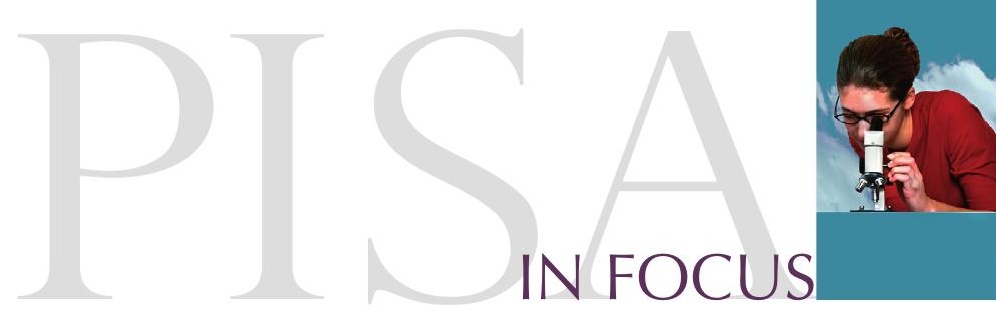

A clear relationship with performance

Students' views on the disciplinary climate in their schools vary not only across countries, but also across schools themselves. On average across OECD countries, $15 \%$ of the variation in students' responses to these questions is attributable to differences between schools; and in the Czech Republic, Estonia, Italy, Japan, Latvia and Slovenia, over $20 \%$ of variation in students' responses is observed between schools.

The association between classroom climate and performance is strong.

The disciplinary climate in the classroom and school can also affect learning. Classrooms and schools with more disciplinary problems are less conducive to learning, since teachers have to spend more time creating an orderly environment before instruction can begin. In 61 countries and economies that participated in PISA 2009, students in schools where the classroom climate is more conducive to learning tend to perform better.

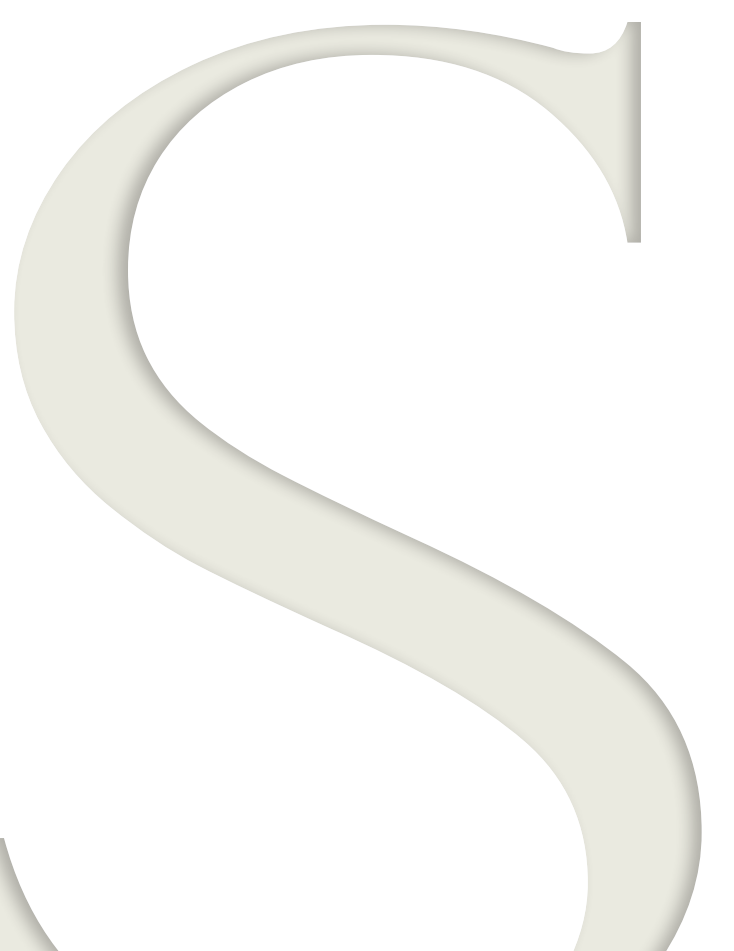

\begin{tabular}{|c|c|c|c|}
\hline \multirow[b]{2}{*}{$\begin{array}{l}\square \begin{array}{l}\text { Positive } \\
\text { association }\end{array} \\
\square \text { No association } \\
\square \begin{array}{l}\text { Negative } \\
\text { association }\end{array} \\
\text { m: missing data }\end{array}$} & \multicolumn{3}{|c|}{$\begin{array}{l}\text { Relationship between average disciplinary climate } \\
\text { in school and... }\end{array}$} \\
\hline & $\begin{array}{l}\text {...average } \\
\text { socio-economic } \\
\text { status of students } \\
\text { in school }\end{array}$ & $\begin{array}{l}\text {...student } \\
\text { performance } \\
\text { in reading }\end{array}$ & $\begin{array}{l}\text {...student } \\
\text { performance } \\
\text { in reading, } \\
\text { after accounting } \\
\text { for students' } \\
\text { and schools' } \\
\text { socio-economic } \\
\text { status, demographi } \\
\text { profile, and various } \\
\text { school features }\end{array}$ \\
\hline \multicolumn{4}{|l|}{ Australia } \\
\hline \multicolumn{4}{|l|}{ Austria } \\
\hline \multicolumn{4}{|l|}{ Canada } \\
\hline \multicolumn{4}{|l|}{ Chile } \\
\hline \multicolumn{4}{|l|}{\begin{tabular}{|l} 
Czech Republic \\
Denmark
\end{tabular}} \\
\hline \multicolumn{4}{|l|}{\begin{tabular}{|l} 
Estonia \\
\end{tabular}} \\
\hline \multicolumn{4}{|l|}{\begin{tabular}{|l} 
Finland \\
\end{tabular}} \\
\hline \multicolumn{4}{|l|}{ Germany } \\
\hline \multicolumn{4}{|l|}{ Greece } \\
\hline \multicolumn{4}{|l|}{\begin{tabular}{|l} 
Hungary \\
Iceland
\end{tabular}} \\
\hline \multicolumn{4}{|l|}{\begin{tabular}{|l|} 
Ireland \\
\end{tabular}} \\
\hline Israel & & & \\
\hline Italy & & & \\
\hline Japan & & & \\
\hline $\begin{array}{l}\text { Korea } \\
\text { Luxembourg }\end{array}$ & & & \\
\hline Mexico & & & \\
\hline Netherlands & & & \\
\hline New Zealand & & & \\
\hline Norway & & & \\
\hline Poland & & & \\
\hline Portugal & & & \\
\hline Slovak Republic & & & \\
\hline Slovenia & & & \\
\hline Spain & & & \\
\hline Sweden & & & \\
\hline Switzerland & & & \\
\hline Turkey & & & \\
\hline United Kingdom & & & \\
\hline United States & & & \\
\hline OECD average & & & \\
\hline Albania & & & \\
\hline Argentina & & & \\
\hline Azerbaijan & & & \\
\hline Brazil & & & \\
\hline Bulgaria & & & \\
\hline Colombia & & & \\
\hline Croatia & & & \\
\hline Dubai (UAE) & & & \\
\hline Hong Kong-China & & & \\
\hline Indonesia & & & \\
\hline Jordan & & & \\
\hline Kazakhstan & & & \\
\hline \begin{tabular}{|l|} 
Kyrgyzstan \\
\end{tabular} & & & \\
\hline Latvia & & & \\
\hline \begin{tabular}{|l|} 
Liechtenstein \\
\end{tabular} & & & $\mathrm{m}$ \\
\hline \begin{tabular}{|l|} 
Lithuania \\
\end{tabular} & & & \\
\hline \begin{tabular}{|l} 
Macao-China \\
\end{tabular} & & & $\mathrm{m}$ \\
\hline Montenegro & & & $\mathrm{m}$ \\
\hline \begin{tabular}{|l|} 
Panama \\
\end{tabular} & & & \\
\hline \begin{tabular}{|l|} 
Peru \\
\end{tabular} & & & \\
\hline Qatar & & & \\
\hline \begin{tabular}{|l|} 
Romania \\
\end{tabular} & & & \\
\hline \begin{tabular}{|l} 
Russian Federation \\
\end{tabular} & & & \\
\hline Serbia & & & \\
\hline \begin{tabular}{|l|} 
Shanghai-China \\
\end{tabular} & & & \\
\hline \begin{tabular}{|l|} 
Singapore \\
\end{tabular} & & & \\
\hline \begin{tabular}{|c|} 
Chinese Taipei \\
\end{tabular} & & & \\
\hline \begin{tabular}{|l|} 
Thailand \\
\end{tabular} & & & \\
\hline \begin{tabular}{|l} 
Trinidad and Tobago \\
\end{tabular} & & & \\
\hline \begin{tabular}{|l} 
Tunisia \\
\end{tabular} & & & \\
\hline \begin{tabular}{|l} 
Uruguay \\
\end{tabular} & & & \\
\hline
\end{tabular}

Note: OECD countries are shown in black.

Source: PISA 2009 database; PISA 2009 Results: What Makes a School Successful? Resources, Policies and Practices, Tables IV.4.2 and IV.2.14c.

StatLink 年ils $\mathrm{http}: / / \mathrm{dx}$.doi.org/10.1787/888932343285 
Schools with more positive disciplinary climates are also those with other characteristics that are closely related to better performance. For example, these schools tend to have more advantaged student populations. In 36 countries and economies, there is positive relationship between the schools' disciplinary climate and the average socio-economic status of their students.

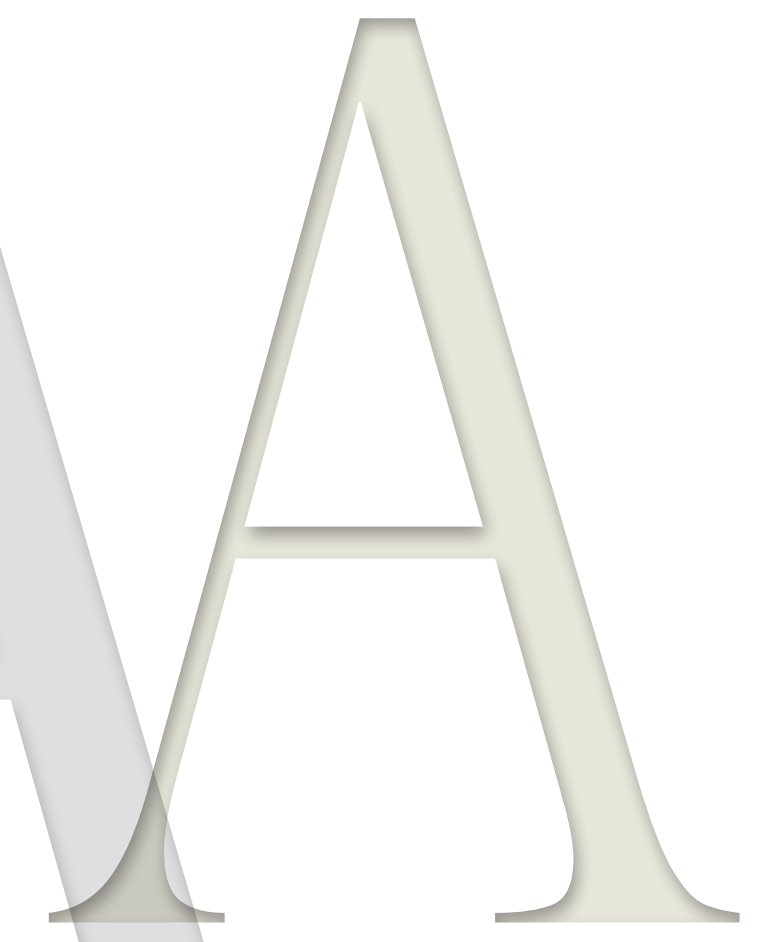

But even after accounting for the socio-economic status and demographic profile of students and schools and various other school characteristics, such as the educational resources available to the school, school governance, and the assessment and accountability arrangements in place, in 31 countries and economies, schools with a more positive disciplinary climate tend to perform better. Disciplinary climate is one of few school-level characteristics that show a significant positive relationship with performance consistently across countries, even after accounting for other school features and students' background. In fact, the strong relationship between students' socio-economic status and disciplinary climate suggests that the impact of socio-economic status on student performance can be weakened by a positive disciplinary climate in school.

The bottom line: A disciplinary climate that is conducive to learning is not only positively related to student performance, but results from PISA suggest that it can weaken the impact of students' socio-economic status on performance.

\section{For more information}

Contact Miyako Ikeda (Miyako.IKEDA@oecd.org)

See OECD (2010), PISA 2009 Results: What Makes a School Successful? Resources, Policies and Practices, Volume IV, PISA, OECD Publishing.

\begin{tabular}{ll}
\hline Visit & Coming next month \\
www.pisa.oecd.org & What can immigrant students tell us \\
www.oecd.org/pisa/infocus & about education systems? \\
\hline
\end{tabular}

